\title{
Comparative Ecological Based Life Cycle Assessment of Multi- Crystalline PV Technology and Coal Electric Power
}

\author{
Benjamin Lang* and Anthony Halog*
}

\author{
The University of Queensland, School of Geography, Planning and Environmental Management, Brisbane, \\ Australia
}

\begin{abstract}
Multicrystalline (multi-Si) photovoltaic (PV) technology is increasingly common throughout Australia and the developed world, as renewable energy technologies become viable electrical generation alternatives to coal and nuclear power. We have examined the cradle-to-grave life cycle of a $3 \mathrm{kWp}$ multi-Si PV system within Australia. The highest contribution of environmental impacts results from the usage of fossil fuel energy resources and their emissions at the pre-production and manufacturing stages. We analyze the impacts of multi-Si technology on ecosystem goods and services (EGS) and compared it with impacts resulting from coal power electricity. For 3kWp multi-Si system, coal, crude oil and iron ore were the critical resources consumed from the lithosphere while the public supply of water was consumed from the hydrosphere. For coal power electricity, coal and water were the resources most consumed from both the lithosphere and hydrosphere. However the resource consumption from coal power electricity is significantly larger than that of multi-Si PV. Coal power electricity is also responsible for much greater energy and exergy consumption compared to multi-Si PV. The main ecosystem disturbances resulting from the lifecycle of a $3 \mathrm{kWp}$ multi-Si unit affect supporting and regulating services though these disturbances are considerably lower than the services impacted from coal power electricity. The study concludes that similar analysis performed on another PV technology would provide a greater understanding to the Eco-LCA results for multi-Si PV technology, particularly with relation to exergy analysis.
\end{abstract}

Keywords: Eco-LCA, multi-Si PV, ecosystem goods services, solar, exergy, coal.

\section{INTRODUCTION}

\subsection{Background}

With heightened awareness regarding the limited availability of non-renewable resources and global warming brought by fossil fuel consumption, renewable energy production such as solar photovoltaic (PV) technology is playing a larger role both in Australia and across the world. Since the beginning of the $21^{\text {st }}$ century, solar power usage has been increasing rapidly in Australia with $400 \%$ growth between 2010 and 2013 [1]. Concurrently, the prices of PV systems have steadily decreased as the average size of installations has increased [1]. As geochemically scarce metals (e.g. rare earth metals/elements) have become indispensable for many emerging technologies [2], developing more powerful yet efficient solar panel systems is a top priority as nations and industries seek to reduce resource consumption and GHG emissions.

\subsection{Solar PV in Australia}

Photovoltaic energy conversion is primarily dependent on surface level solar insolation, with other variables such as rainfall or temperature having

*Address correspondence to these authors at the School of Geography, Planning \& Environmental Management, The University of Queensland, Brisbane QLD 4072, Australia; Tel: (+61) 7336 56141; Fax: (+61) 7336 56899; E-mails: benlang84@gmail.com, a.halog@uq.edu.au minimal impacts [3]. This makes Australia a prime location for widespread PV usage. Although solar radiation is abundant in Australia, total electricity and heat production from non-renewable resources released 199.2 million tons of $\mathrm{CO} 2$ emissions during the first decade of the $21^{\text {st }}$ century [4]. Australia still obtains $75 \%$ of its electricity from coal power [5]. Nevertheless, the Australian government will invest over $\$ 10$ billion into clean energy projects through the Clean Energy Finance Corporation [6], with solar PV being a major component of the investment. Australia, along with Japan, Germany, Italy and the UK will account for $3 / 4$ of all residential PV installations this year [7]. The solar PV industry has been expanding rapidly within Australia in recent years. As of October 2012, some 858,000 homes in Australia (more than $10 \%$ of homes) have solar PV panels with an installed capacity of just under $2 \mathrm{GW}$, with the millionth Australian home having solar PV by the end of June 2013 [8]. Around 240,000 additional solar PV panels will be installed in Australia in 2013 with a combined capacity of $740 \mathrm{MW}$ [9]. The PV market in Australia will continue to grow between 6G and as much as 10GW by 2017 [7]. Currently, Queensland has the most PV installations of any Australian state [9] and in many of its suburbs, over $40 \%$ of households have solar panels [10]. Stoppato (2008) claims that with respect to PV technology, Australia has the highest potential for $\mathrm{CO} 2$ mitigation due to both high solar radiation and energetic mix based on fossil fuels. 


\subsection{Mono-Si and Multi-Si}

Crystalline silicon-based solar panels encompass monocrystalline silicon-based (mono-Si) PV and multicrystalline silicon-based (multi-Si) PV and together they account for around $80 \%$ of the global PV market [11]. Multi-Si PV can have conversion efficiency up to 0.18 [12] and lifespan reaching 28 years [13]. Mono-Si PV has the highest conversion efficiency with some models achieving greater than 0.20 [14]. This is the highest efficiency in the photovoltaic industry. Solar panels based on crystalline silicon must be in use for about 2 years before the cumulative energy they supply balances the energy required to produce them also known as the energy-payback time (EPBT) [11]. Mono$\mathrm{Si}$ cells typically have higher efficiencies and higher manufacturing costs than multi-Si cells [5]. However, multi-Si PV dominate the solar cell industry due to their durability and low cost [15].

\subsection{Attributional LCA for Multi-Si PV}

The lifecycle stages of a multi-Si PV system, beginning with resource extraction and continuing through end-of-life decommissioning and disposal, are examined further in the "Supplementary Data" section with a functional unit of $1 \mathrm{~m} 2$ multi-Si panel. The extraction of silicon from silica is expensive and requires a high amount of electrical energy [13]. The total energy required to manufacture a multi-Si PV system is about $1060 \mathrm{kWh} / \mathrm{m} 2$ [16]. Major gas emissions from the manufacturing process include $\mathrm{CO} 2, \mathrm{SO} 2$ and nitrous oxide [17]. Nearly all of the fossil fuel energy and resource consumption, carbon dioxide production and other emissions associated with multi$\mathrm{Si}$ PV systems arise from the pre-production and manufacturing stages of the lifecycle. Furthermore it was determined that heavy metals, toxic gas and GHGs are the main emissions from multi-Si PV technology [18]. The highest contribution of environmental impacts by multi-Si PV panel is due to the use of fossil energy resources and their respective emissions.

\section{METHODOLOGY}

\subsection{Eco-LCA}

This study utilizes the eco-LCA methodology for assessing impacts of the lifecycle of multi-Si PV technology and coal electric power generation. EcoLCA is a physically based approach to account for the role of ecosystem goods and services (EGS) including supporting services, regulating services, provisioning services and cultural services [19]. This approach is valuable since attributional type LCA fail to account for the role of EGS derived from natural capital and because the scientific understanding of ecosystem production functions is often omitted from decisions and policy-making [20]. EGS, also referred to as natural capital, are crucial for sustainability since they provide the basis for all biological activities [19]. Furthermore, eco-LCA can account for regulating services of ecosystems by representing their flows in physical units (i.e. exergy represented in J) [20].

We have performed an eco-LCA for $3 \mathrm{kWp}$ multi-Si PV technology using the Eco-LCA approach as proposed by the Center for Resilience at The Ohio State University. Additionally, we have performed an eco-LCA of coal electric power generation. The functional unit selected was 1 meter squared $(1 \mathrm{~m} 2)$ of multi-Si PV which equates to 32 watts of coal electric power. LCl data for two 3kWP systems was gathered from the online Swiss database Ecolnvent. Each of these systems was installed in Switzerland in the year 2000 and both have a total installed capacity of $12.7 \mathrm{MWp}$. The first system is a façade-integrated unit while the second system is a slanted-roof installation. The model names of the systems were not made available however the Ecolnvent dataset numbers are 1762 for the façade-integrated unit and 1770 for the roof-integrated unit. Both systems have a life expectancy of 30 years. The $\mathrm{LCl}$ data for these systems was combined and averaged into the eco-LCA spreadsheet template before being imported back into the software. Consequently no economic sector provided by software was selected as the basis for analysis. The closest economic sector provided by the tool that could have been applied to this study was "semiconductor and related device manufacturing" however this included data not specific to multi-Si PVs and only focused on the industry within the United States. The façade-integrated and roof-integrated PV systems were chosen due to their prevalence in Australian residential developments. The results of their LCls, which were nearly identical in most categories, were averaged in order to provide an understanding of the lifecycle impacts generated by common multi-Si PV systems. Furthermore, examining both roof-integrated and façade-integrated provides a broader context on the impacts of multi-Si PV systems.

The coal electric power generation industry used with the Eco-LCA tool represents the fossil fuel electric power generation in the United States. The facilities 
analyzed use fossil fuels such as coal, oil, or gas, in internal combustion or conventional steam process to produce electric energy. This industry sector was selected because it most closely represents the coal power industry within Australia and due to its accessibility within the Eco-LCA tool.

\subsection{Limitations to Case Study}

There are a few limitations to the methodology used in this eco-LCA. First is our usage of secondary data. Second is our usage of data representing the average environmental burden for producing a finished product. The data used for this eco-LCA was data typically used for an attributional LCA. The next major limitation is the selection of Swiss-installed systems as opposed to those installed within Australia. This was done because the LCl data for these systems was readily available in the Ecolnvent database and we were unable to gain access to the Australian $\mathrm{LCl}$ database known as AusLCl. The developer of AusLCI was contacted but specific data relevant to Queensland was either not provided or not in their possession. Nevertheless, the $3 \mathrm{kWp}$ systems assessed are widespread throughout Australia as previously stated. Moreover, although the $\mathrm{LCl}$ data does provide cumulative exergy demand values for all resources including metals, it does not break down the "metals" category for each of the specific metals used in the production of multi-Si PV as the Eco-LCA data template requires. We acknowledge that the values for each metal could be less accurate and that the results for each of these may likewise not be precise for Australian $3 \mathrm{kWp}$ systems since the Swiss systems require heavy-duty installations to withstand snow loads. The LCl data from Ecolnvent also includes nuclear energy consumption within the Swiss PV lifecycle even though nuclear power is not used in Australia. Lastly, the industry sector selected for coal power generation was based on data provided by the Eco-LCA software based on an integrated ecological-economic model of the US economy. The specific industries such as coal, oil, or gas were not broken down within the sector and do not reflect the Australian economic model.

\section{THEORY}

\subsection{Exergy in Eco-LCA}

Eco-LCA methodology correspondingly accounts for the exergy flow during processes and lifecycles. Exergy is defined as the maximum energy used that can be obtained as a system achieves equilibrium with a reference environment [21]. More simply, exergy is work or the ability to produce work [22]. Exergy analysis uses the conservation of mass and conservation of energy principles together to evaluate the usage of energy and can be used to improve the efficiency of a system [23]. Additionally, thermodynamic analysis of energy systems has been used in the design, simulation and performance of PV technology [24]. Thermodynamic methods have been increasingly popular for LCA evaluation due to their scientific precision and ability to account for a variety of resources in terms of a common unit [21].

Exergy analysis can be used for PV technology evaluations to allow for more representative development. In order to obtain the exergy efficiency of a PV system, the exergy input and output should be available [24]. Exergy efficiency provides a greater understanding of PV performance than energy efficiency since it stresses that both external losses and internal irreversibilities must be taken into account. Exergy efficiency of PV systems is highly dependent on daily solar radiation and radiation intensities [23]. PV exergy efficiency decreases with an increase in ambient temperatures and wind speed [24] and thus varies greatly depending on location. Exergy analysis has been done on a number of photovoltaic thermal $(\mathrm{PV} / \mathrm{T})$ systems, though few if any have been done on crystalline-based PV technology.

\section{RESULTS}

\subsection{Mass Flow}

Mass flow accounts for the material content of each resource consumed over the course of the lifecycle of multi-Si PV systems. Mass flow from the atmosphere and biosphere for coal power is much greater than for the lifecycle of multi-Si PV. Figure 1 below shows the amount of resource consumption comparing the lifecycles of the two forms of energy. Figure 2 then displays resource consumption for the lithosphere. Consumption of metals from the lithosphere was much greater for the lifecycle of coal power electricity than multi-Si as shown in Figure 3. This comparison clearly indicates that the lithosphere is more greatly impacted by coal power electricity generation than the lifecycle of a $3 \mathrm{kWp}$ multi-Si system. Mass flow from the hydrosphere, water (powerplant), occurs during the lifecycle of coal power electricity, though not from the lifecycle of multi-Si PV. This consumption of water is considerably greater than the consumption of any other resource from the lithosphere, hydrosphere or biosphere. 
Table 1: Comparing PV Electric Generation to other Sources of Electricity in Australia [12]

\begin{tabular}{|c|c|c|c|c|c|c|}
\hline $\begin{array}{c}\text { Nuclear } \\
\text { (TWh) }\end{array}$ & $\begin{array}{c}\text { Hydro } \\
\text { (TWh) }\end{array}$ & $\begin{array}{c}\text { Coal } \\
\text { (TWh) }\end{array}$ & $\begin{array}{c}\text { Oil } \\
\text { (TWh) }\end{array}$ & $\begin{array}{c}\text { Gas } \\
\text { (TWh) }\end{array}$ & $\begin{array}{c}\text { PV and } \\
\text { others (TWh) }\end{array}$ & $\begin{array}{c}\text { Total } \\
\text { (TWh) emissions }\end{array}$ \\
\hline \hline 0.0 & 17.0 & 186.7 & 2.4 & 34.0 & 2.4 & 242.5 \\
\hline
\end{tabular}

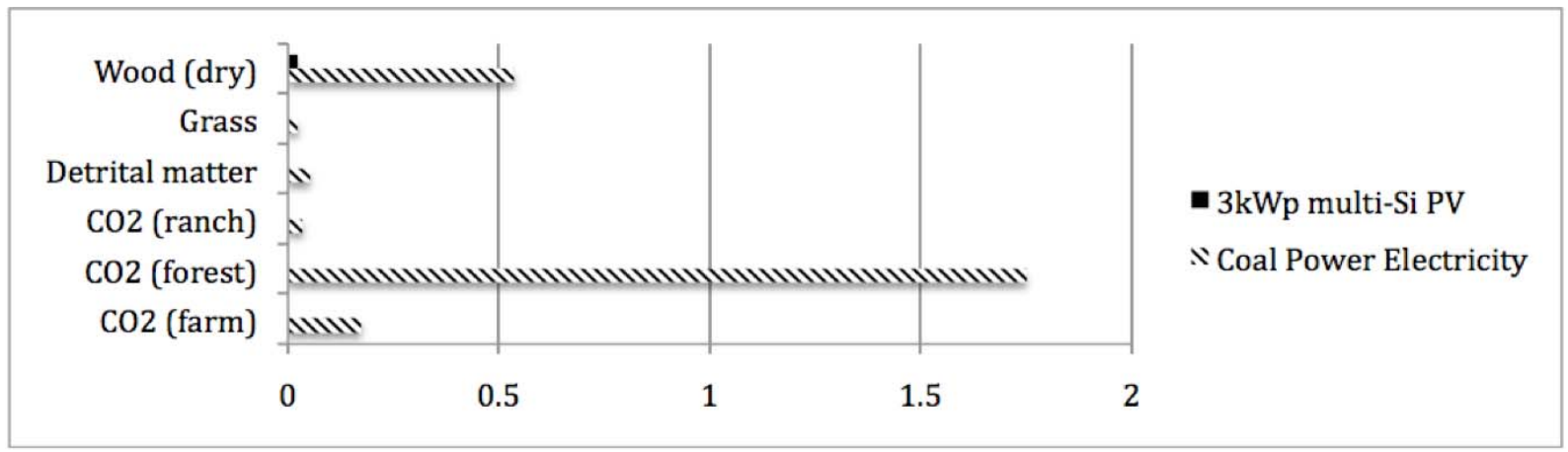

Figure 1: Mass flow in $\mathrm{Kg}$ from the atmosphere and biosphere. Solid black is barely visible in this comparison due to the great amount of mass flow occurring from coal power electricity.

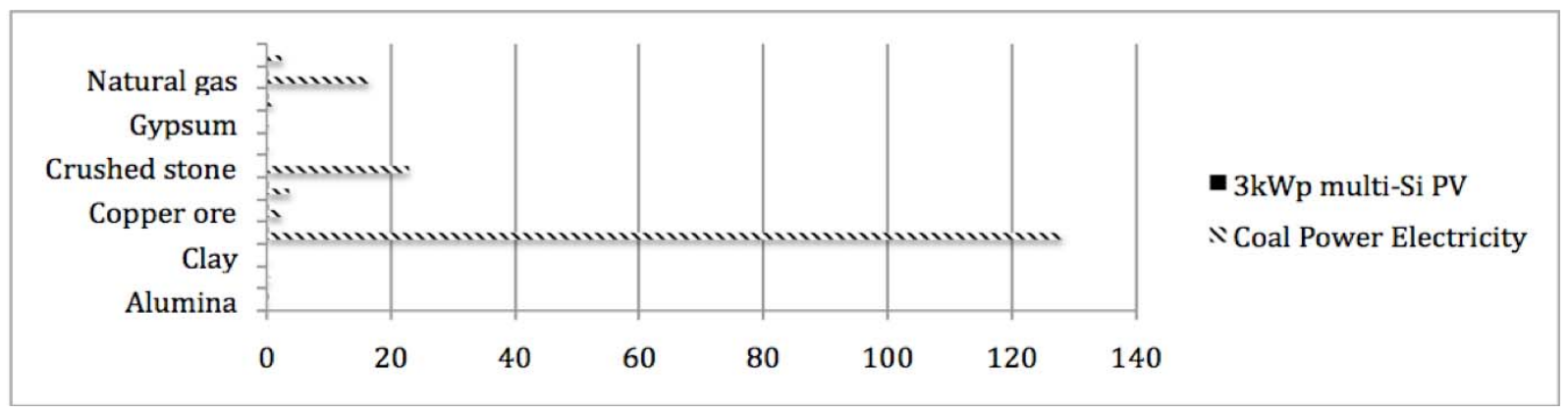

Figure 2: Mass flow in $\mathrm{Kg}$ from lithosphere. Solid black is barely visible in this comparison due to the great amount of mass flow occurring from coal power electricity.

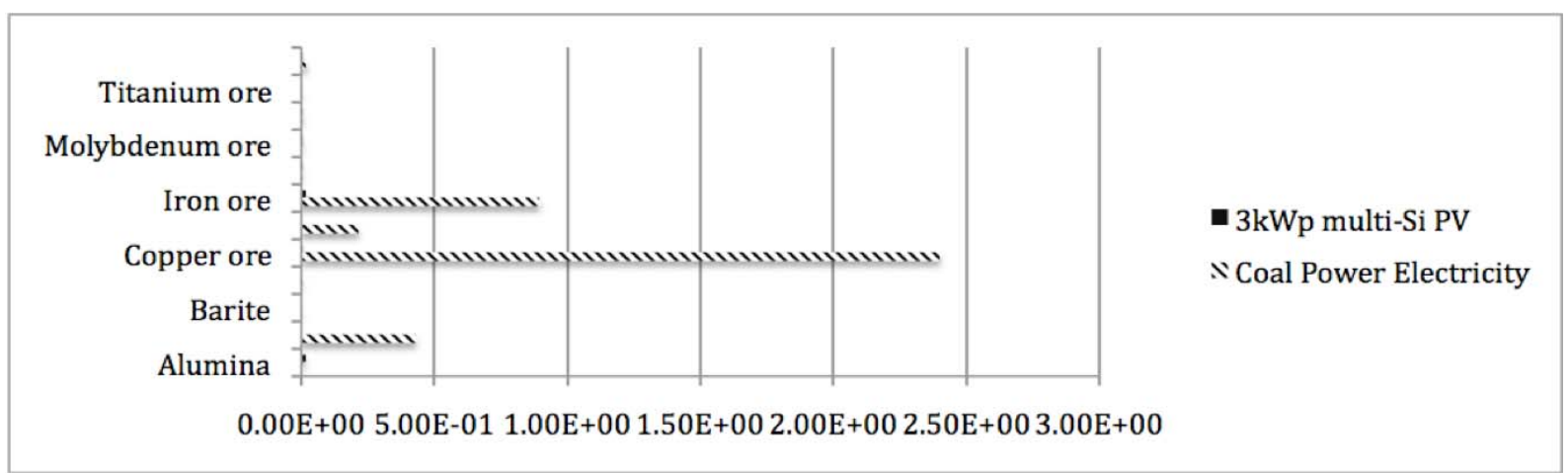

Figure 3: Mass flow in $\mathrm{Kg}$ of metals from lithosphere. Again, solid black representing 3kWp multi-Si PV is not visible in this comparison.

For $3 \mathrm{kWp}$ multi-Si system, coal, crude oil and iron ore were the critical resources consumed from the lithosphere while the public supply of water was consumed from the hydrosphere. For coal power electricity, coal and water were the resources most consumed from both the lithosphere and hydrosphere. Since the lithosphere provides ecosystem services such as sequestration of $\mathrm{CO} 2$, barriers for pollutants and supporting terrestrial life [25], the demand for raw materials for multi-Si PV adds pressure to the components of the ecosystem that are dependent on these. By comparison, the pressures on the hydrosphere are more severe than those on the lithosphere, which can lead to impacts on hydrological 


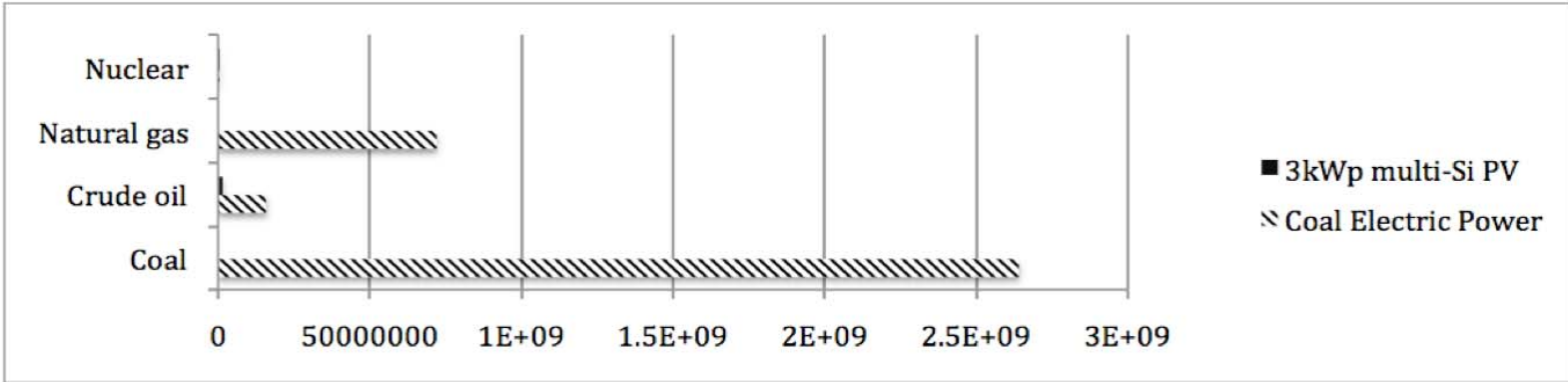

Figure 4: Main sources of energy flows during lifecycle in J. More energy is consumed from non-renewable resources by coal power electricity.

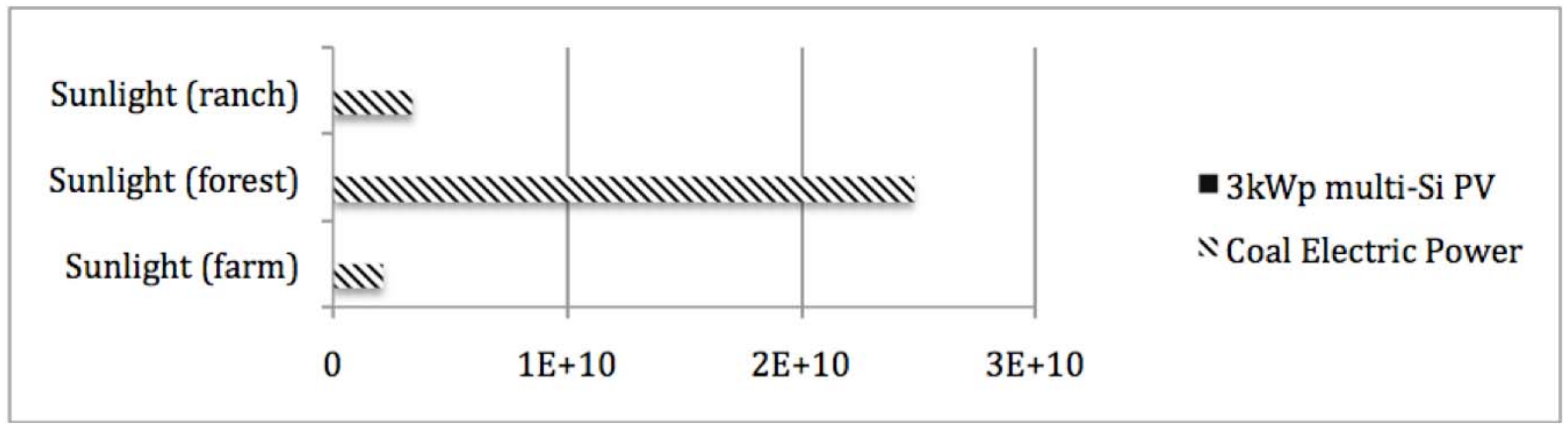

Figure 5: Main sources of energy flows during lifecycle in J. No energy is consumed from renewable resources by $3 \mathrm{kWp}$ multiSi PV.

cycles. The atmosphere and biosphere are also impacted by resource consumption when analyzing mass flow for coal power electricity though much less so for 3kWp multi-Si PV.

\subsection{Energy}

Energy flow, which accounts for the fuel value of resources [19] was analyzed by looking at renewable vs. non-renewable energy consumption. Coal power electricity consumes significantly more energy from non-renewable energy than $3 \mathrm{kWp}$ multi-Si PV, Figure 4. Additionally, coal power electricity consumes more energy from renewable resources as shown in Figure 5. Fossil fuels and sunlight are responsible for the greatest consumption of energy primarily during for coal power electricity. Thus, greater energy consumption occurs from coal power electricity compared to multi-Si PV.

\subsection{ICEC}

Exergy is able to quantify both material and energy sources, which allows for more complete analysis than mass or energy [19]. ICEC, industrial cumulative exergy consumption, values consider cumulative exergy consumption in the industrial links of the production of multi-Si PV systems and coal power electricity [26]. There is greater ICEC from coal power electricity than multi-Si PV. This is illustrated in Figures 6 and 7 below.

Exergy is consumed from the lithosphere and hydrosphere for both sources of electricity though

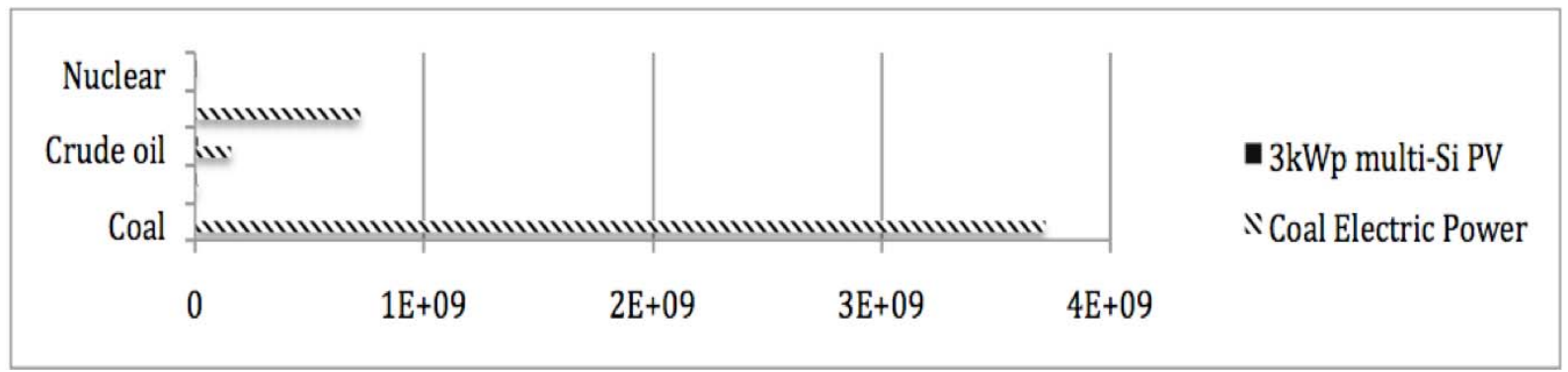

Figure 6: Main sources of ICEC flow during lifecycle in $\mathrm{J}$ for non-renewable resources. Similar to energy consumption, more exergy is consumed from coal power electricity than multi-Si PV. 


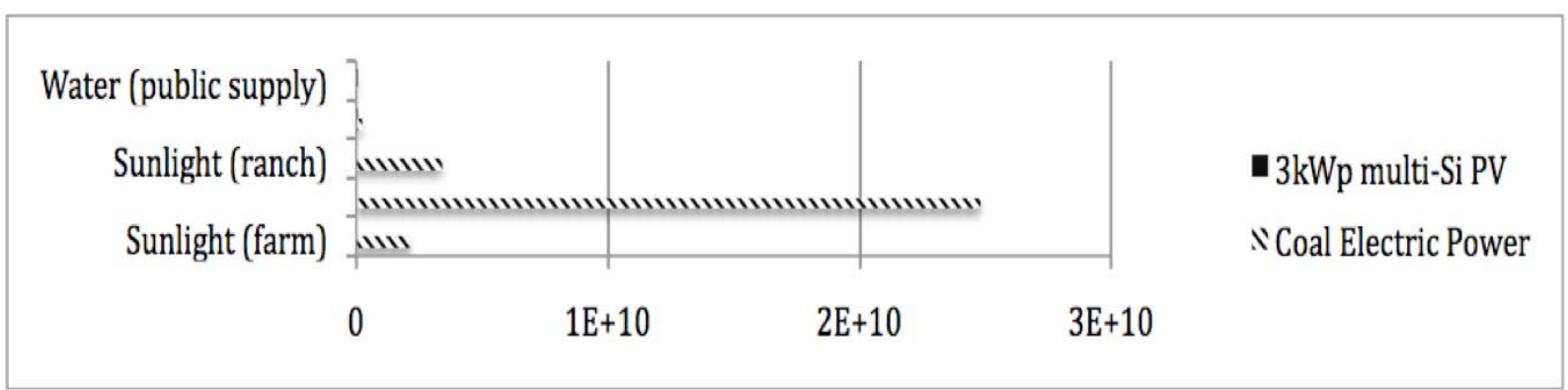

Figure 7: Main sources of ICEC flow during lifecycle in $\mathrm{J}$ for renewable resources. Similar to energy consumption, more exergy is consumed from coal power electricity than multi-Si PV.

significantly higher for coal power electricity as shown in the above figures. The majority of exergy consumption coming from energy resources such as coal, natural gas, water supply and sunlight. The results of Eco-LCA suggest that multi-Si PV utilizes a resource's exergy more efficiently than coal power electricity.

\subsection{ECEC}

ECEC, ecological cumulative exergy consumption (also known as emergy), is an extension of ICEC to include exergy consumption in ecosystems [26]. There were no ECEC values provided for $3 \mathrm{kWp}$ multi-Si PV so no comparison was made for this indicator and only coal power electricity was reviewed. From the lithosphere, coal, crushed stone, crude oil and natural gas are responsible for the greatest consumption of ECEC. The lithosphere is responsible for over $90 \%$ of the ECEC during the lifecycle of coal electric power generation, although water (power plant) was also a significant source of ECEC from the hydrosphere. ECEC occurs from the atmosphere in the form of $\mathrm{CO} 2$, though this does not compare to the exergy consumption that occurs in the lithosphere and hydrosphere.

\subsection{Land Usage}

Land usage of multi-Si PV is very low compared to coal power electricity. The total land use for $3 \mathrm{kWp}$ multi-Si PV is 0.023 square meters compared to 5.1 square meters for coal power electricity (this includes land disturbance). This has to do with the fact that the models reviewed were roof and façade-integrated mounted on existing structures. Solar PV demand, already more than $10 \%$ of homes in Queensland use PV technology, will continue to grow to as much as $10 \mathrm{GW}$ by 2017 [8]. Figure 9 displays a comparison of land usage between the two energy sources.

\section{DISCUSSION}

\subsection{Analyzing Impacts on EGS}

The lifecycle of multi-Si PV systems has far less impacts on EGS than coal power electricity. The water and energy consumed for coal power electricity impacts the hydrosphere and lithosphere through resource consumption significantly compared to $3 \mathrm{kWp}$ multi-Si PV. Greater quantities of non-renewable resources are consumed during the lifecycle of coal power electricity. GHG emissions from coal power electricity also impact the atmosphere much more than

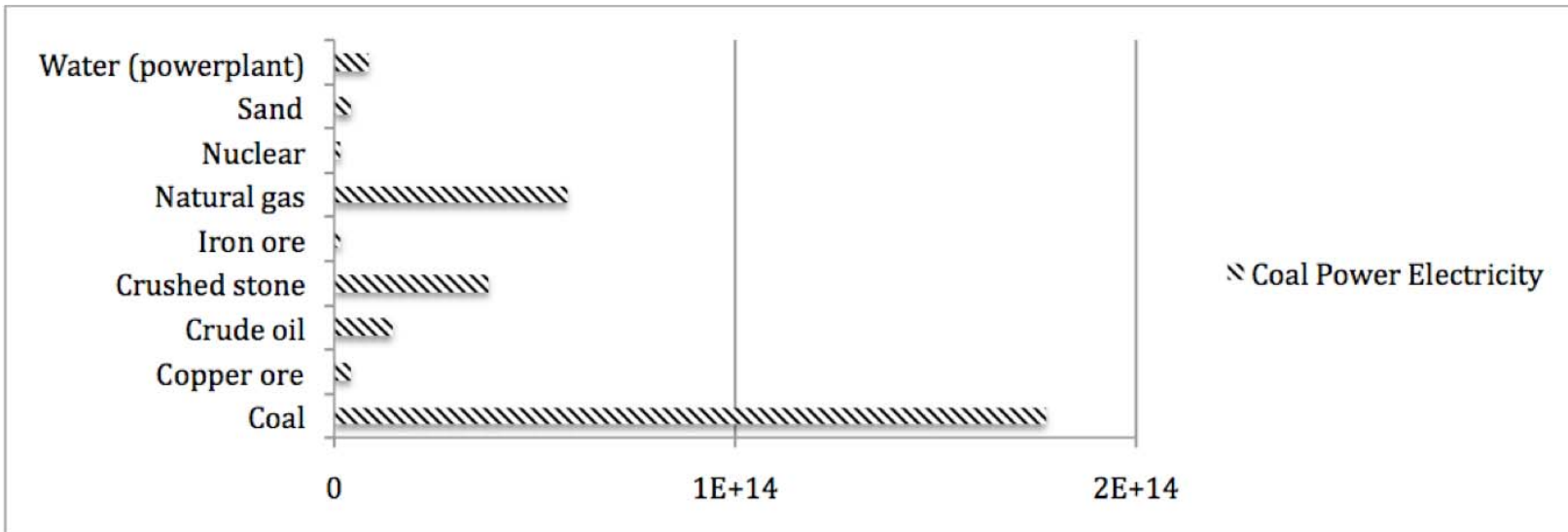

Figure 8: Main sources of ECEC for coal power electricity in solar equivalent Joules (seJ). 


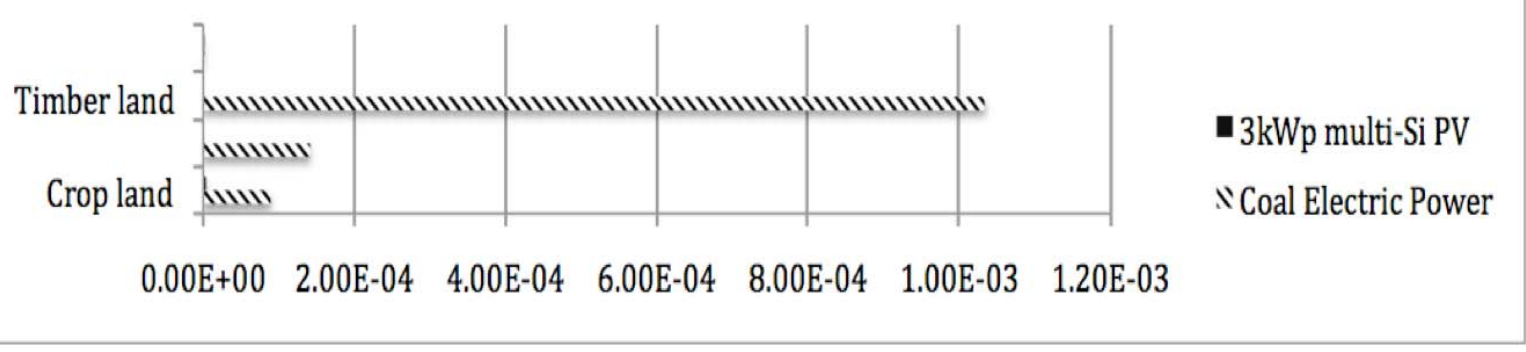

Figure 9: Land usage in acres. Solid black representing $3 \mathrm{kWp}$ is barely visible in Urban and industrial land occupation.

the 3kWp multi-Si PV. Impacts on the biosphere do not appear to be significant for either coal power electricity or multi-Si PV as most of the resources consumed are not relied upon by living organisms. However, the consumption of resources such silicon and its connection to the PV market are not as explicitly detailed by the tool. Furthermore, decommissioning or disposal of multi-Si PV systems does not appear to have impacts on the biosphere as the waste is contained within landfills or recycling facilities. Supporting and regulating services like air quality regulation, $\mathrm{CO} 2$ sequestration, climate regulation and hydrological cycles are more affected by coal power electricity than multi-Si PV technology. The growing solar industry within Australia would greatly relieve impacts on EGS that result from the coal power industry.

\subsection{Further Research}

There are many opportunities for further research. First, given the presentation and analytical depth of the Eco-LCA results, it would be worthwhile to compare the ecosystem impacts of multi-Si PV technology with another PV technology such as mono-Si or thin film. Besides multi-Si, mono-Si remains the most commonly installed PV technology within Australia and the rest of the developed world, although thin film technology has been noted for its more efficient manufacturing process and less resource requirements. An examination of the impacts on ecosystem services comparing these technologies would provide greater insight on the environmental pressures of a multi-Si PV system. Moreover, the exergy consumption and efficiency of a multi-Si PV system can be better understood when compared to other common PV technologies. A comparison of exergy values would provide better understanding of the effectiveness of multi-Si PV due to the lack of available data on PV exergy consumption.

Another possible approach would be to perform a hybrid-LCA, perhaps utilizing both the ecosystem approach and a consequential approach to evaluate economic implications relating to multi-Si PV technology. This would require more diverse data as well as access to different modeling tools. It could also provide a more quantitative context to the impacts on ecosystem services from the lifecycle of multi-Si PV.

Another potential extension could provide further analysis on the extent of the impacts on ecosystem services highlighted by the results of the Eco-LCA tool. The tool did not detail which specific ecosystem services were impacted, such as carbon sequestration or water filtering, just the component of the environment from which the impact is felt. Research into the physical ramifications of these impacts would lead to greater clarity on the issue.

\section{CONCLUSION}

This study examined the ecosystem impacts from the cradle-to-grave lifecycle of a typical $3 \mathrm{kWp}$ multi-Si PV system, and compared these impacts to coal power electricity. It determined that ecosystem services from the lithosphere and atmosphere are the most impacted by this lifecycle. Land usage is considerably lower for PV systems, and should decrease further as module efficiency increases. Exergy was consumed during most stages of the lifecycle, particularly from energy resources and metals. Due to the lack of reliable data for conducting exergy analysis for other PV systems, it was difficult to determine the significance of the exergy used. A hybrid approach incorporating multi-regional input/output (MRIO) analysis may not only increase understanding of EGS impacts resulting from multi-Si $\mathrm{PV}$ technology but also enable policies that serve as a catalyst for further innovation of $\mathrm{PV}$ and other renewable energy opportunities.

\section{ACKNOWLEDGEMENTS}

We would like to thank Professor Bhavik Bakshi and student Erin Gibbemeyer of Ohio State University for assisting us with the Eco-LCA tool. Additionally, we 
would like to thank Binod Neupane of the University of Maine for providing supporting information in regards to Eco-LCA tool.

\section{ABBREVIATIONS}

$$
\text { EGS }=\text { ecosystem goods and services }
$$

Multi-Si PV = multicrystalline photovoltaic

Mono-Si PV = monocrystalline photovoltaic
ICEC = industrial cumulative exergy consumption

ECEC = ecological cumulative exergy consumption

\section{REFERENCES}

[1] APVI. Australian PV market since April 2001. Australian PV Institute, 2015 [cited 2015 April 26]; Available from: http://pvmap.apvi.org.au/analyses

[2] Wä ger PA, Lang DJ, Wittmer D, Bleischwitz R, Hagelü ken C. Towards a more sustainable use of scarce metals: a review of intervention options along the metals life cycle. Gaia 2012; 21: 300-9.

[3] Geyer R, Stoms D, Kallaos J. Spatially-explicit life cycle assessment of sun-to-wheels transportation pathways in the US. Environ Sci Technol 2013; 47: 1170-6. http://dx.doi.org/10.1021/es302959h

[4] Sivaraman D, Horne RE. Regulatory potential for increasing small scale grid connected photovoltaic (PV) deployment in Australia. Energy Policy 2011; 39: 586-95. http://dx.doi.org/10.1016/j.enpol.2010.10.030

[5] Hsu DD, O'Donoughue P, Fthenakis V, et al. Life cycle greenhouse gas emissions of crystalline silicon photovoltaic electricity generation. J Industrial Ecol 2012; 16: S122-S35.

[6] CEF. An overview of the Clean Energy Legislative Package. Canberra: Clean Energy Future Australian Government 2012.

[7] Parkinson G. Australia may have up to $10 \mathrm{GW}$ of solar PV by 2017. Renew Economy [Internet] 2013 March 13, 2013.

[8] Hannam P. Solar panel take-up heads towards the millionth home. The Sydney Morning Herald. 2012 October 10, 2012; Sect. Environment.

[9] Parkinson G. Australian PV installations to fall, but solar hot water to rise. Renew Economy [Internet]. 2013 March 13, 2013.

[10] Dunbar A, Egan R. Australia reaches 4GW installed solar. Australian PV Institute, 2014 [cited 2015 April 25]; Available from: http://www.pv-tech.org/news/ja_solar_starts_ production of mwt solar cell technology from ecn

[11] Everts S. Making Solar Panels Greener. Chemical \& Engineering News [Internet] 2011; 89(8): 37-8. http://dx.doi.org/10.1021/cen021511170038
Osborne M. JA Solar starts production of MWT solar cell technology from ECN. PV Tech [Internet]. 2013 April 27, 2013. Available from: http://www.pv-tech.org/news/ja_solar_ starts_production_of_mwt_solar_cell_technology_from_ecn

[13] Stoppato A. Life cycle assessment of photovoltaic electricity generation. Energy 2008; 33(2): 224-32. http://dx.doi.org/10.1016/j.energy.2007.11.012

Solarplaza. Top 10 World's Most Efficient Solar PV Modules (Mono-Crystalline). Solarplaza; 2012 [cited 2013 April 27]; Available from: http://www.solarplaza.com/top10-crystallinemodule-efficiency/

[15] Ibrahim A, El-Amin AA. Etching, Evaporated Contacts and Antireflection Coating on Multicrystalline Silicon Solar Cell. International Journal of Renewable Energy Research 2012; 2(3): 356-62.

[16] Papadopoulou EVM. Photovoltaic Energy. Photovoltaic Industrial Systems. Berlin: Springer Berlin Heidelberg 2011; pp. 31-55. http://dx.doi.org/10.1007/978-3-642-16301-2 4

[17] Tsoutsos T, Frantzeskaki N, Gekas V. Environmental impacts from the solar energy technologies. Energy Policy 2005; 33(3): 289-96.

http://dx.doi.org/10.1016/S0301-4215(03)00241-6

[18] Fthenakis VM, Kim HC, Alsema E. Emissions from Photovoltaic Life Cycles. Environmental Science \& Technology 2008; 42(6): 2168-74. http://dx.doi.org/10.1021/es071763q

[19] CFR. Ecologically-Based Life Cycle Assessment (Eco-LCA). Columbus, Ohio: The Ohio State University; 2012 [cited 2013 February 21]; Available from: http://resilience.eng.ohiostate.edu/eco-Ica/index.htm

[20] Neupane B, Halog A, Lilieholm RJ. Environmental Sustainability of Wood-derived Ethanol: A Life Cycle Evaluation of Resource Intensity and Emissions in Maine, USA. Journal of Cleaner Production 2012.

[21] Baral A, Bakshi BR. Thermodynamic Metrics for Aggregation of Natural Resources in Life Cycle Analysis: Insight via Application to Some Transportation Fuels. Environmental Science \& Technology 2010; 44(2): 800-7. http://dx.doi.org/10.1021/es902571b

[22] Wall G. Exergy, Ecology and Democracy - Concepts of a Vital Society or A Proposal for An Exergy Tax. In: Szargut J, et al, editor. ENSEC'93, International Conference on Energy Systems and Ecology; Krakow, Poland: EOLSS 1993; p. 111.

[23] Saidur R, BoroumandJazi G, Mekhlif S, Jameel M. Exergy analysis of solar energy applications. Renewable and Sustainable Energy Reviews 2012; 16(1): 350-6. http://dx.doi.org/10.1016/j.rser.2011.07.162

[24] Akyuz E, Coskun C, Oktay Z, Dincer I. A novel approach for estimation of photovoltaic exergy efficiency. Energy 2012; 44(1): 1059-66. http://dx.doi.org/10.1016/j.energy.2012.04.036

[25] UKEOF. UK-Environment Observation Framework (UK-EOF) Statement of Need: Lithosphere \& Pedosphere Observation Requirements. Swindon, United Kingdom: UK-EOF 2010.

[26] Ukidwe NU. Thermodynamic Input-Output Analysis of Economic and Ecological Systems for Sustainable Engineering. Columbus, $\mathrm{OH}$ : The Ohio State University 2005. 